\title{
Looking Back and a Little Forward: Reflections on Professionalism and Teaching as a Profession
}

\author{
By Magali Sarfatti Larson
}

\begin{abstract}
Magali Sarfatti Larson's The Rise of
Professionalism was a path-breaking

analysis of professions as they

organized their labor and won privilege

in the industrial capitalist market. We
\end{abstract}

asked her if she would reflect on what

she wrote in the 1970s, and on how

the conditions of possibility for

professionalism have changed since

then, with an example from the

present moment: she chose $\mathrm{K}-12$

teaching. --The editors
A second edition of The Rise of Professionalism was published in 2012, but I wrote the book in the early 1970s. Back then, the broad concern with the constitution and uses of expert knowledge, present in America since its founding, was fraught with anguished criticism of how expertise was applied to the conduct of the Vietnam War. Experts were suspect.

However, also in 1972, David Halberstam had precisely accused the elite in charge of our foreign and military policy of ignoring the authentic expertise produced by professionals at State and in the Defense Department. And forty years after Vietnam, as we marched toward another war on flimsy justifications and forged evidence, experts at the Central Intelligence Agency were asked to set aside what their professional knowledge stood for. When I approached the professional rite of passage of writing my doctoral thesis, our trust in expertise, the effects of this trust, and the real power that experts had were questions that hovered in the background of my work.

My first steps toward studying professions were prompted by practical experiences. I was interested, initially, in the attempts to unionize employed architects in the Bay Area; knowing that even high level credentials did not do much to prevent job insecurity and dubious career paths, I was surprised to hear the organizers report that many architectural employees considered unionization unprofessional. Similarly, as a lecturer at San Francisco State, I had seen the faculty strike of 1968 greeted by other colleagues and the press as "behavior unbecoming" for professionals. This was quite different from what I knew had happened (and was still happening) in Europe. 
Both the modern professions and the bureaucratic organizations of big business belong to the process of rationalization of capitalist societies. For many sociologists, the central social functions that professions serve explained the attributes that were hashed and rehashed in multiple definitions: the extensive knowledge professionals must acquire, the specificity of their work, the reliable uniformity of their behavior, their privileged social status and the unity of their organized group - the "community within a community." In this perspective, professions are agents of order because of their special knowledge and their ethics, while lesser occupations aspire to follow a path that leads, presumably, to the same desirable end point.

The analyses and descriptions I read were mainly derived from the established professions of medicine and law, whose defining characteristics became the parameters by which to judge "semi-professions." This did not dispel my feeling that "profession" and "professional" were judgments of value, as often as descriptive or analytical categories. The sociologists of the Chicago school confirmed this sentiment, for their empirical work refuted the idea that there were differences of essence between professions and less exalted occupations. My focus then became the process-or, as I called it to mark the power of agency, the collective project- by which these privileged occupations had become what the public and many sociologists assumed they were. I did not expect to be original, and I do not believe I was, except that I may have been the first trying to do something different in the sociology of professions.

In this essay, I will briefly recapitulate what I said in the book and distinguish what I would like to have done differently from what I still consider worth taking seriously. Finally, instead of speculating about the future, I will offer some reflections about the profession of teaching. Teachers are under great stress today and even under direct attack in many parts of the country. They are the kind of professional that I have been for most of my adult life. Theirs is the largest category of "organizational professions" that serve the public. Their fate is tied in with our public schools and, since Jefferson, with how we see the fate of the republic.

\section{What I did and what I did wrong}

The established professions claim to have specialized knowledge that guides their actions in the service of society. This expertise, or knowledge in action, is certified; certification justifies, as Everett Hughes pointed out, the license they receive to act. What he called the professions' mandate goes further, for it gives them authority to recommend how others ("the public") ought to act (Hughes, 1971, 374-386). Historically, mandate was used by authoritative professionals to discipline and control lesser occupations and poorer citizens. That license should become mandate and extend from the profession to its individual members involves risks that can be great, as the poor clients of some court-appointed lawyers often find out at their own expense. Indeed, one-time certification does not guarantee that the certified professional's knowledge is deep enough, or specialized enough, or sufficiently up-todate, or even adequate. But this goes back to the professions' self-organization and self-discipline, which do not appear as problems in most functionalist accounts. I was interested in how the professions as we knew them had gained such authority, and whether their mandate had emerged seamlessly from their pre-industrial past, from which they took some forms of organization and rites of passage, or, in many cases, their names.

I doubted that there could be a general theory of professions for all times and all places, so it was easy to make the pragmatic decision of restricting my research to the "Anglo-American" version of professionalism and leave aside the civil service model predominant in continental Europe. In England after 1825 and in the United States after 1840, groups of practitioners organized themselves to provide training, certification, and, ideally, self-regulation, in waves of association that took place in less than six decades; the historical matrix in which they operated had changed profoundly from earlier times and continued changing. With much work and many revisions, I put together not a theory, but an interpretation of the British and American professional phenomenon after the late eighteenth and nineteenth century industrial revolution.

\section{Both the modern professions and the bureaucratic organizations of big business belong to the process of rationalization of capitalist societies.}

Karl Polanyi's great work, The Great Transformation, marked my entire way of seeing more lastingly than Marx, on whose framework Polanyi had built his own, as he moved toward a powerful explanation of the triumph of the market, the social resistance to its destructive effects, and the collapse he witnessed after 1929. My intellectual debt to Polanyi should have settled the accusation of economic reductionism that any evocation of Marxist concepts seems to stir up. Although some critics complained about the Marxist terminology I used (we all had different intellectual fashions), few misread my argument as narrowly socioeconomic, or as denouncing professions for self-interested "conspiracies against the laity" as G.B. Shaw said in The Doctor's Dilemma.

Extracting structural change from the history of reform movements enabled me to see professionalization as a project that aimed at translating one order of scarce resources into another. As a historically specific form of organizing work, profession depended on establishing structural links between relatively high levels of formal education and relatively desirable positions or rewards in the social division of labor. On the one hand, we have what we now call credentials, formal, certifiable, and certified education under professional control; on the other hand, we have market positions that guarantee a respectable social status, a relatively decent living, and a measure of autonomy at work. Credentials and also market shelters because the excesses of unregulated competition were the main incentive for reform. Indeed, social mobility was a strong and recurrent impetus for the practitioners involved 
in professionalization. Once established, these structural links would channel and constrain further purposive actions.

The first part of the book focuses on what was necessary to establish a protected market. The expert knowledge that professionals transact on the market is a fictitious commodity in Polanyi's sense: the producers themselves have to be "produced" and their services made recognizable, different from alternative forms of service, and hopefully better. Educated labor, however, is embodied in individuals that have not been produced for sale, even if their services were intended for exchange. The "branding" of their special services cannot emerge from the market itself. It depends on practitioners consenting to be trained and certified by the accepted institutional centers. Even in societies of a liberal stamp, where professional reform arises from a competitive market, these movements address their claims to the state, as the ultimate institutional guarantor.

\section{The greatest flaw of The Rise of Professionalism is its abstraction and generality.}

Analyzing the belated success of medicine as the archetypal profession, I became convinced that knowledge, be it in Latin or vernacular, be it classic or "modern," abstract or empirical, restricted or created in excess by over-training, was never sufficient by itself to establish the superiority of trained professionals vis-à-vis their sometimes less trained rivals. I never denied the necessity of training in a knowledge that was formal, codified, standardized, verified, and probably as advanced as possible; in the long run, superior efficiency marked a profession's victory over its rivals. But the comparison between medicine and engineering (which I still consider a core part of my book) taught me the importance of structural elements in the potential market for medicine as well as that of the cultural and political context. My conclusion was not that engineering had failed to professionalize, but that medicine's path was unique, even if it inspires emulation. In fact, engineering appeared as the precursor of most of the professions that would develop later in the nineteenth and twentieth centuries, which I called organizational professions.

I started emphasizing the changed world to which professionals were responding throughout the nineteenth century. However, they also had a past. As one classic English author put it, "The new professional men brought one scale of values-the gentleman's-to bear upon the other-the tradesman's-and produced a specialized variety of business morality which came to be known as 'professional ethics' or 'etiquette'" (Reader, 1966: 158159). I too looked at professions under the light of the "anti-market principles," in which Polanyi rested the "selfprotection of society." There was limited empirical evidence of the professions' "service ideal." However, if the professional project required creating a not yet developed market for expertise, the occupation had to advance the function it claimed to serve. The service ideal could then be rephrased as R.H. Tawney's "principle of purpose," involving the professions with the consequences of savage industrialization. At the individual level, the professional work ethic stressed the intrinsic value of work, blending the notion of calling with craftsmanship ideals that were increasingly negated by capitalist industrialization.

The greatest flaw of The Rise of Professionalism is its abstraction and generality. They come from my dependence on the secondary sources that were available, not primary materials. Moreover, I limited my study to a woefully incomplete comparison of England and the United States because I could not possibly do more at the time. I emphasized differences as much as commonalities between England and the United States before moving to analyze the rise of corporate capitalism and organizational professions in America. At that point, the model based on early twentieth century medicine clearly did not offer a realistic portrait of the work conditions of new occupations (social work, librarianship, teaching at various levels, public health inspectorates, and the like) that claimed to have expert skills. In sum, I had not meant to say that all professionalization processes aimed toward the same goals and arrived at the same place, for I saw the model of profession as historically specific and historically limited. But despite the different conditions of twentieth century organizational professions, the model drawn from medicine and the law could function as a vigorous ideology of what is desirable in the world of work.

\section{Analyzing the belated success of medicine as the archetypal profession, I became convinced that knowledge, be it in Latin or vernacular, be it classic or "modern," abstract or empirical, restricted or created in excess by over-training, was never sufficient by itself to establish the superiority of trained professionals vis-à-vis their sometimes less trained rivals.}

Undoubtedly, I exaggerated the discontinuities between pre-industrial past and market society; a more attentive observation of history would often have dispelled them. But even the profession of law, which was the first to disengage itself in fourteenth century Europe from the tutelage of the church, did not develop until the nineteenth century the stable and intimate connection with training and examinations (or "objectively" verified competence) that came to be the hallmark of profession. Status advantages are not distributed randomly: in most countries, the same "old" professions are in some way protected by law from unqualified competitors, while the new occupations sheltered by market closure tend to perform activities in the national interest. But even if privileged workers put their educational advantages to comparable uses, this does not mean that any occupation with special skills will seek, much less obtain, professional status. 
That was not a mistake I committed; but my overly schematic account was most wrong in implying that even the classic professions existed at the onset as a unified actor. On the contrary, professional reformers had to create the very field in which reform could advance-the modern profession itself. Elizabeth Popp Berman's compelling study of English medicine from about 1780 to the Medical Reform Act of 1858 shows what an arduous job it was: "more things divided doctors than united them. It took several attempts to create an organization with a strong shared identity to bind doctors together despite the partitions of rank, geography, and tradition" (Popp Berman, 2006: 188). She finds empirical evidence for something that I had emphasized theoretically: work in hospitals provided doctors with an identity-forming organizational base, as collective places of work do for most workers.

I also took too much for granted at the edges of the professional project: I let the university, with which reformers sought a link, and the state, from which they expected institutional sanctions, appear as static audiences, devoid of internal dynamics and motivations of their own. There are many other omissions in my book. Most glaringly, I did not deal at all with the professions' discrimination against women and ethnic and racial minorities. I touched on the effects that the Flexner reform of the medical field in 1910 had on midwives, women, minorities, and poor students, but only in passing. I should have emphasized that the "classic professions" were mostly male and mostly white. Undoubtedly, gender has profoundly marked the professionalization of teaching that Catharine Beecher called "the true and noble profession of women." Much important work on the subject was to come, not only from individual authors but also from institutions like the National Academy of Science or publications like the Journal for Women and Minorities in Science and Engineering, started in 1994.The questions raised by the feminization of professions (about their social advantages, and even about the forms of deployment of expert work) remain open.

Finally, I did not touch directly upon the professions' discursive authority. Public discourse is an elite function, as I showed in my later work on architecture; in many professions, it is centered in the academic or research branch. The authority to speak for the whole field trickles down to the ordinary practitioners: they have not created the discourse that goes with the profession's mandate, but they act within its boundaries

\section{What is still valid?}

First of all, I think it was important to approach professionalization as a historically situated process. For some historians, the rise of social strata that did not depend on the sale of labor power, as factory workers did, but rather on state recognition, was the most significant transformation of the occupational and class structure in nineteenth century England (Perkin, 1989). I did not deal with civil servants, but with groups who were pioneering a characteristically new form of knowledge-based inequality. They too depended on the state for the success of their project. They anticipated what John and Barbara
Ehrenreich called the "professional-managerial class" in 1977 (Ehrenreich and Ehrenreich, 2013).

Later, Andrew Abbott aptly called jurisdictions the recognized claims that tie an occupation to a core set of tasks, and he argued that competition is what moves occupations to strive for jurisdiction; linked by competition, they belong to an ever moving and dynamic system of professions (Abbott, 1988). I think that his emphasis on interdependence and on the "work core" is very important, but my focus was to underline the monopolistic tendencies at the heart of the professional project. Converting one order of scarce resources into possibly another (credentials, as proxies for expertise, into protected opportunities, special status, and work privileges) and protecting scarce resources imply a tendency to monopolize them.

\section{I also took too much for granted at the edges of the professional project: I let the university, with which reformers sought a link, and the state, from which they expected institutional sanctions, appear as static audiences, devoid of internal dynamics and motivations of their \\ own.}

Second, I believe it was right to give engineering as much attention as sociology had previously given to medicine. Indeed, if abstract and esoteric knowledge applicable to areas that are socially important is so fundamental, why has engineering not acquired market power and control comparable to medicine in the United States? An easy answer would be to look at what the profession of medicine has become under the British National Health Service, but that did not apply to the beginning of professionalization. I stand by the structural dimensions of market control that the comparison enabled me to deduce: they form a constellation of structural factors that are variable, and determine conditions more or less favorable to particular professions at particular times.

Favorable conditions include: a widespread, if not universal need for the profession's expertness; a service dispensed in private and not embodied in physical objects (easy to regulate or replicate); a clientele that is not organized; a market that is independent from capital and goods markets; the state's interest in the functions served by the profession; and, last but not least, effective institutions for the production of producers and a welldefined cognitive basis (Larson, 2012: 47-48). Anticipating what will follow, we note that public sector teaching appears at first sight to be favored by an ever-expanding, captive and unorganized clientele, to whom it provides expert services in the relative privacy of the classroom, in a market that is not a market at all but an important apparatus of the state, which has a paramount interest in the performance of this service. For these reasons, indeed, many European states have organized professional 
teaching on the civil service model, especially at the secondary levels, long reserved to social or merit elites.

Thirdly, for professionals to coalesce into a group, their knowledge basis had to be shared, that is codified and standardized; for ". . . the codification of knowledge . . . depersonalizes the ideas held about professional practice and its products. It sets up a transcendent cognitive and normative framework within which, ideally, differences in the interpretation of practice and in the definition of the 'commodity' can be reconciled" (Larson, 2012: 40). Opening the door to "de-standardizing" developments, I added that exceptional skills (even individual genius) rise from what remains indeterminate in the cognitive basis and in the practice of a profession. A foundation in science connects the professional producers with modern society's paramount source of validity; however, the centers for the "production of producers" are themselves in different classes of prestige. The research universities are at the top of the hierarchy; this has been significant, for instance, in the "genealogy of the movement to professionalize teaching." As David Labaree points out, the specialized knowledge that is supposed to guide teachers' practice comes to them from outside their ranks: it is produced, concentrated, and diffused by schools of education, though not by all of them equally (Labaree, 1992).

Much before the information revolution, the second wave of professions developed as providers of expert services within the organizations that employed them. In my view, the supposed conflict between professions and bureaucracy could be dispelled, for it was based on an idealized notion of "free" profession and Weber's model of bureaucracy taken as a totality (Larson, 2012: 190); bureaucracy and professions develop jointly, as capitalist rationalization advances and state power is concentrated. This was conspicuously true of school teaching, which acquired its modern features only with the compulsory education acts that included secondary schooling after World War II.

The subordination of professionals in large organizations inspires much contemporary research on professional work. True, an important category of organizations that we call professional is autonomous. They are medical partnerships, large law and accountancy firms, large engineering and architectural offices, founded and managed by professionals. Except for health professions, the typical clients of these firms are other organizations (either private or public). Today, the large majority of professionals work in organizations, and an increasing number are employed in heteronomous, by contrast with autonomous, organizations: they are not governed by colleagues but by professional managers, like school principals and superintendents, or hospital administrators, or personnel managers of various kinds.

Organizational professions are spawned by the state, the business corporation, the university. Some professions (notably, health professions, social work, teaching, many areas of the law) are crucially involved in the delivery of a service to clients; but those that I called "technobureaucratic" apply their expertise on behalf of the employing organization or of the latter's clients. The orientation to the client is thus a crucial differentiating factor: it distinguishes what T. H. Marshall called "socialized professionalism" from that of the experts ensconced in large organizations (sometimes in enclaves, like scientists or engineers in industry). Indeed, both categories may have to protect their work autonomy and standards, but the situation of "service" professions demands that they do more than just guard against managerial encroachments: even before our time of austerity-as-virtue, they have had to defend the service they perform from cuts in the organizations that deliver it. Whether they engage in alliances with their clients or not, defending their field moves them, in collective self-interest, to advocate social needs and often public goods. It is precisely their conditions of work that call "service" professionals to "promote the performance of function," giving to professionalism the meaning that R.H. Tawney intended: not to make money only, but to "make health, or safety, or knowledge, or good government, or good law" (Tawney, 1948: 94-95). British researchers, in particular, have argued that the ideas of profession and professionalism can be used by management "to control the increasing margin of indeterminacy or flexibility in work." But even though the meaning of professionalism is contestable, there are clear hints in this literature that subordinate professionals are at risk of losing their immunity to top-down reorganization of their work (Fournier, 1999: 301-302).

\section{The subordination of professionals in large organizations inspires much contemporary research on professional work.}

I had considered the role of professionalism as ideology in my book, and I was criticized for it. In a 1980 article I looked directly at what disempowerment could mean (Larson, 1980). Throughout the evolution of capitalism, educated labor, and especially the sectors organized into professions, appeared as the subjective opposite of the industrial working class. Moreover, the engineers and managers that worked directly at the service of capital actually played a large role in dispossessing industrial labor of self-regulation and skills. I doubted that they, or other privileged workers, could experience a comparable deprivation of technical autonomy, even though increasing numbers of credentialed workers had to sell their labor and work as subordinates. At the end of the 1970s, before the boom years of Information Technology, many professional categories faced static if not shrinking labor markets and stagnant salaries. Except for the aggravating circumstances of ballooning student debt and severe fiscal cuts, the situation of educated labor was analogous in its main features to what it is today. But was it, could it be, analogous to that of industrial workers, despite the outsourcing of skilled white-collar tasks?

Both proletarianization and professionalization touch collectivities, not individuals only. However, the production of producers embeds expertise in individuals, creating at least the illusion of individual choice and individual mastery 
upon one's skills. This, indeed, is one of the strong and enduring features that attract people toward professional training and careers. Moreover, most employers prefer to hire people with degrees, not because of any specialized knowledge they may possess, but because the offer is there and it demonstrates a minimum of "middle-class" virtues. Thus, college degrees establish a binary division in the social division of labor, a fragile protection against even more insecure, worse paying, and more subordinate forms of work. Oversupply, however, is a problem: it devalues first level degrees, stimulating both jurisdictional disputes in specialized areas and "academic escalation" in fields that invent a research function, with the attendant M.A.s and doctorates.

Professions like architecture and journalism suffer from economic trends and crises independent of the educational system. For organizational service professions, cost efficiency has meant intensification and overload, accompanied by increased regulation and performance metrics. Particularly in the United States, teaching, social work, criminal justice occupations, and others are cut down by fabricated fiscal austerity. With this background, I shall now turn to the not-quite-full-fledged profession of teaching, as it weathers a powerful storm.

\section{Thinking about teachers' professionalism}

The teaching occupation lives, as I have said, within large and heteronomous organizations-the school districts. Even if, at the local level, schools may not be large, teachers in them are still the subordinate implementers of policies decided elsewhere. Today, the storm that threatens teachers, most especially in large cities, circles back to the question with which I started: is it "professional" to join a union? Unions have been under attack i

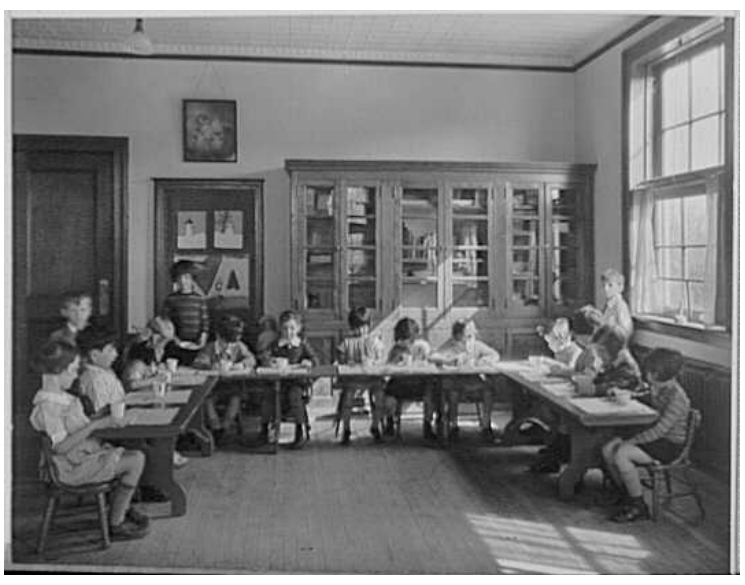

ELEMENTARY SCHOOL ROOM. COURTESY OF LIBRARY OF CONGRESS
4. And, lastly, lack of recognition of the teacher as an educator in the school system, due to the increased tendency toward "factoryizing education," making the teacher an automaton, a mere factory hand, whose duty it is to carry out mechanically and unquestioningly the ideas and orders of those clothed with the authority of position, and who may or may not know the needs of the children or how to minister to them." (in Diane Ravitch's blog, September 12, 2012, italics mine)

In front of an organization run by male administrators and professors, Haley, the first woman to address the assembly from the floor, spoke of unions being the only way to achieve the "educational ideal" by applying "the most advanced education theory." She fused teachers' professionalism with their working conditions and demanded a share of power, claiming "The same things that are a burden to the teacher are a burden also to the child. The same things which restrict her powers restrict his powers also" (in Hlavocik, 2012: 510). Then as now, coalitions led by business and middle-class reformers opposed teachers' power, either in their unions or in the schools. Instead, they offered educational credentials as a proxy for professionalism, classroom autonomy, and, for a few teachers recruited to different training programs, a passage into administration (Lazerson, 1984: 269). The stage was set then, much before the momentous postwar expansion of education, for what teachers must also confront today: centralized administrative power, technocratic leadership by outsiders, and a business model whereby market principles penetrate the state under the guise of reform.

Let us consider some numbers. In the United States, school teachers are by far the largest occupation among those listed as "Management, Professional and Related" by the Bureau of Labor Statistics, every sector of work since the mid-1970s, but in $\mathrm{K}-12$ teaching, they are often presented as the opposite of professionalism, defined from above.

The story goes back to the first period of teacher unionism; it started with Margaret Haley's historical speech on the floor of the National Education Association in 1904, where she outlined what teachers lacked and what schools needed to be fit for a democracy:

1. Greatly increased cost of living, together with constant demands for higher standards of scholarship and professional attainments and culture, to be met with practically stationary and wholly inadequate teachers' salaries.

2. Insecurity of tenure of office and lack of provision for old age.

3. Overwork in overcrowded schoolrooms, exhausting both mind and body. followed by registered nurses. In 2008, teachers of all kinds, including preschool and kindergarten, special ed, "other teachers and instructors" and substitutes were over 6 million; in 2012, their ranks had dwindled to 5,860,000 but still represented $4.1 \%$ of the total employed labor force, $10.8 \%$ of "managerial, professional and related" and $68 \%$ of the education sector. $\mathrm{K}-12$ teachers are a mass occupation; at $35.4 \%$ they have the highest unionization rate in the country. Even in the United States, where anything public is often disparaged, teachers massively provide a public good: in 2009, public schools taught $90 \%$ of all students, a proportion that has increased in the last decade and is expected to continue rising. Undoubtedly, the profession has been created by the advancement of state functions. Universal mandatory education in the twentieth century has been the watershed that category spread out at many levels, still predominantly female, highly educated, and, in many countries but not transformed this occupation into what it is today: a huge 
ours, following a civil service model. It also introduced very high expectations around a universal service provided by an apparatus of the state.

Teachers' salaries loom large, especially in locally financed schools and revenue-starved municipalities; but today, above all, their competence is under attack. Teachers are judged by the "product" they put out, and they are found wanting, as if they were primarily responsible for what kids learn and do outside of school or how they test. It is not idle to note that physicians are not answerable for the paltry and worsening performance of U.S. health indicators compared to advanced (and not so advanced) countries.

\section{The authority of the principal is the second form of dominance and it affects teachers most directly. Historically, professional school administrators are the creature of bureaucratic reform: at the end of the nineteenth century, the mostly male administrators moved to create distinctive programs of training, based on methods borrowed from business and economics}

A premise is therefore in order: first of all, the strong correlation between student achievement and family background has been repeatedly confirmed, and not only in the United States. While there is a test score gap between privileged and underprivileged students everywhere, the United States has the second highest rate of child poverty (23\%) second only to Romania among the 35 richest countries (UNICEF, 2012). The economist Helen Ladd writes, "The low average test scores of U.S. students largely reflect our extremely high poverty rate and our relative lack of attention to the overall wellbeing of our children" (Ladd, 2012, 211).

Second, this does not mean that teachers should not try their best with disadvantaged children. Many, if not most, teachers do try, even in our chronically handicapped urban schools. Convergent studies document the unusually strong service ethic among a high percent of those who enter teaching (Ingersoll, 2003: 168-169). In my research, I saw this sense of mission produce something I called utopian pragmatism: a utopian belief in the quasi sacred function of schooling nourishes the commitment to one's daily work with hope that at least the most resilient kids can be rescued from lives of deprivation and poverty (Larson, 1995). It may not be totally unrelated to the teachers' sense of mission that, in the last decade, disadvantaged students in the United States have made substantial gains in international comparisons, while the more advantaged have not (Carnoy and Rothstein, 2013).

Political authorities also try. They regularly attempt to make every child achieve "proficiency," however illusory and variable its measurement. The top-down cycles of reform make teachers accountable, but not principals, or district officials, or the very structure of schools, or the students' background, augmenting teachers' mistrust of programs that invariably come from non-educators. Recent legislation and programs pushed by rich philanthropic foundations have scapegoated teachers as inveterate shirkers, making them accountable for the impossible tasks that No Child Left Behind and Race to the Top have imposed on the nation's public schools. This is a bitter paradox if we consider the forms of dominance that afflict American teachers. Dominance ultimately curtails the autonomy conceded to teachers in their classrooms, and we must repeat that autonomy, a hallmark of professionalism, meant that teachers had discretion in choosing the methods by which to teach contents they seldom chose.

\section{Teachers' salaries loom large, especially in locally financed schools and revenue-starved municipalities; but today, above all, their competence is under attack.}

The effects of dominance do not flow here from a clearly leading profession such as physicians are in the medical sector, where they have long controlled the curricula and activities of nurses and other professionals (Freidson, 1970, 137). Teachers are subordinate, first of all, to the power vested in a bureaucratic structure of command that issues top-down edicts even in a system as decentralized and incoherent as ours. The school apparatus manifests its power at national, state, and local levels; in the United States, the last two are endowed with exceptional economic and political leverage over schools, which contribute to the irrevocable diversity of school sites. Diversity determines in large part the disparity of results and poses intractable obstacles to the teaching occupation's unity.

The authority of the principal is the second form of dominance and it affects teachers most directly. Historically, professional school administrators are the creature of bureaucratic reform: at the end of the nineteenth century, the mostly male administrators moved to create distinctive programs of training, based on methods borrowed from business and economics, after bureaucratization had firmly placed them apart and above the mostly female teachers (Callahan, 1962). Unlike physicians, school administrators seldom have superior knowledge or expertise about teaching, but they have superior power. The principal mediates between higher administrative levels, elected school boards, and her professional staff while enjoying unmediated power within her school; therefore, much depends on her orientations and personality. In my research, the principal was pivotal for the participation of teachers in committees of governance (according to some teachers, she mandated it!). Depending on the principal, such councils may have only advisory functions (and look like mere windowdressing) or decision-making capacities, which practically all teachers consider requisite for making teaching more of 
a profession (Feistritzer, 2011). Participation in decisionmaking, however, seldom includes teachers in the drafting of disciplinary policies or the adjudication of discipline, which are crucial for classroom efficiency (Ingersoll, 2003, 144-148)

The third form of dominance affects in a deep way what teachers ought to know, what they learn and their claims of competence. Teachers, indeed, are formed in teacher colleges or universities, not in $\mathrm{K}-12$ public schools; their training centers are quite dissimilar and unequal in effectiveness, resources, and prestige. High-status universities long denied equal respect to their colleges of education but showed them the road: inventing a "science of education" provided a capital asset for the mobility project of teacher educators. Their quest for status and the science of teaching advanced together, from the mid-1960s on, in those universities that provide members and, especially, leaders to groups like Carnegie and Holmes, the main advocates of teacher professionalization since $A$ Nation at Risk appeared in 1983 (Labaree,1992). In the hands of university-based educators, pedagogical science aimed at rationalizing not only the school, but also the classroom, under the rule of experts.

The first two forms of dominance are relatively simple expressions of power. A teacher who had taken the "alternative route" (from being a professional trainer in a large insurance company) told me that nothing surprised her in the organization of the school:

I expect it in any job situation in which you have a superior. . . unless you are the person in charge, someone is always going to tell you what to do, how to do it, what you can't do, what you should do, and it's just a matter of how you deal with it. It's contradictory [with being a professional] but no more so than in the corporate world ... [There,] all they wanted was the bottom line and I was tired of that. In moving to teaching I felt I was in control of myself, in control of my classroom, hopefully, that I could be doing something to enrich somebody else's life, however small." (Larson, 1995)

As I mentioned, some historians of education think that control over the classroom was left to teachers in exchange for exclusion from policy-making. In this they were treated like industrial workers, albeit with necessary skills: prevented from organizing for decades by explicit antiunion rulings, excluded from management, yet required to have credentials in order to implement policy with a large degree of autonomy and flexibility. It is not surprising that teachers should not compare themselves to the idealized medicine-based model of liberal profession, by virtue of which sociologists have declared them a "semi-profession." Professionalism is their individual autonomy in the classroom, although their superiors often call "professional" the willingness to comply with directives from above, and call resistance "unprofessional."

Some of the characteristic problems of teaching in the United States arise in the third dimension of dominance, that of professional training: here, the "science of teaching" is designed to legitimize our fluctuating efforts to certify and thus, presumably, professionalize all the teachers. Indeed, in its 1986 report, the Carnegie Task Force on Teaching as a Profession recommended certification "because the certificate will be an unambiguous statement that its holder is a highly qualified teacher" and "can expect to be eagerly sought by states and districts that pride themselves on the quality of their schools" (in Labaree, 1992: 131). Today, many reformers vehemently criticize an education that neither emphasizes how to teach in practice, nor the incorporation of the best technologies, nor the mastery of a subject (Keller, 2013).

Except perhaps as students in the best graduate schools of education, working teachers do not participate in codifying a knowledge they are supposed to apply in practice. In truth, the complexity and variety of classroom realities defy codification (the variables are simply too many) just as they ultimately defeated the purposes of taylorized mass instruction. Yet, in 1986, the Holmes Group announced that "the promise of a science of education is about to be fulfilled," and encouraged prospective teachers to train "in a form of knowledge about teaching practice that is specialized (no longer dependent on [other] disciplines), authoritative (scientific), and inaccessible to the lay person (counter-intuitive)" (Labaree, 1992: 134). The relation between the theoretical knowledge that researchers produce and teachers' practice appears dubious to many practitioners, who see university theory as thoroughly disconnected from the complex reality of the classroom; this may in part be due to the ideology of individualism that transforms the American teacher's real isolation into valued professional autonomy, and collegial support into an admission of weakness.

Ellen Lagemann argues that university researchers turned away from John Dewey's educational philosophy to the detriment of practical knowledge. Because schools were the domain of female teachers, the mostly male education researchers ignored the ideal of the school as a laboratory for collaborative research; in their quest for status, they needed to be taken seriously by other male researchers and male school administrators, to whom they sought to dispense knowledge, consultation, and prescriptive guidelines (Lagemann, 2000). It should be

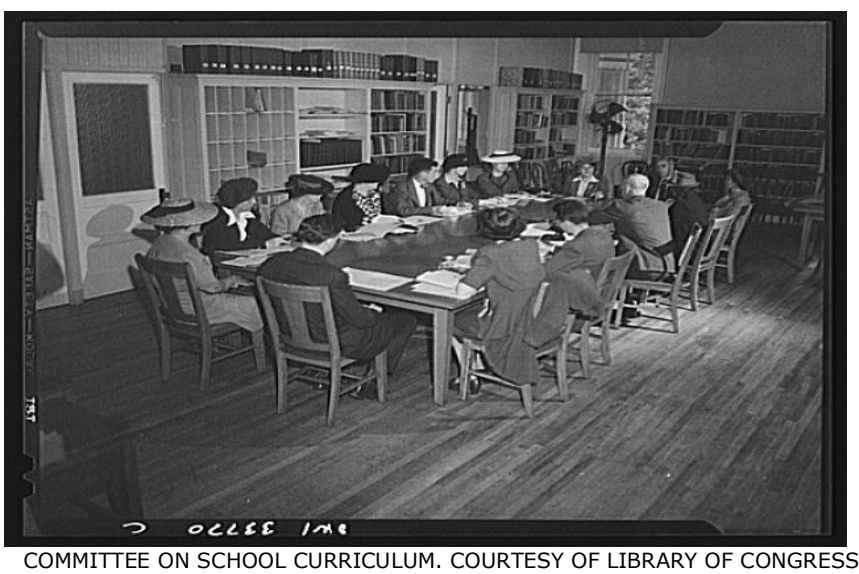

clear at this point that teacher educators and researchers 
followed what I have called a collective mobility project, along the established professional lines. K-12 teachers did not.

Now, the feminization of teaching and the separation between universities and teacher practice exist in all advanced economies. The work of teachers, however, may be particularly difficult in the United States and not only because teacher professionalization has been weak. Child poverty and persistent racism coalesce in the difficult situation of our urban schools. Relying on local funding and refusing to mitigate the deep inequality among schools (we do not like taxes, and much less taxes "for other people's children") are part of our unfortunate "exceptionalism." So is the enormous variation from state to state, politically enshrined in federal education policies; it joins the influence of diverse and even outlandish local voices in conspiring against national standards and curricula. Rather than seeking to establish serious guidelines about content, many American reformers exhibit a stubborn fondnessinherited from scientific management-for measurement and tests. It periodically leads educational authorities into maniacal bouts of testing, taken as proxy for student learning.

\section{Teachers are well aware of their occupation's low prestige, but perhaps less aware of the public esteem in which they are held, second only to the military in perceived contributions to society's well-being.}

With No Child Left Behind, testing penetrated the classroom, contaminating teachers' control over their class objectives and forcing neglect of whatever did not prepare the students to be assessed, in reading and math only. These one-shot exams, by which teachers themselves and their schools would most unfairly be judged, have led to documented abuses but have not been abandoned (Ravitch, 2011, Ch.6): testing, in fact, was even applied prematurely (and resisted) to the Common Core in New York, placing its promising development at risk (Kirp, 2013).

Furthermore, the United States is unique in enjoying the mixed blessing of philanthropic private foundations, interested in education for their own institutional agendas. With investments that seem very small compared to the $\$ 638$ billion the U.S. government spent in elementary and secondary education in 2009-10, they wield enormous influence. Helped and energized by public and recurrent fears of American educational decline, the Gates, Broad, and Walton Family foundations lead a varied field. They push reforms guided by the principles of data collection (with standardized test scores taken as data), merit pay based on test scores (as reward and punishment for "dutyshirking" teachers), school "turnaround" or else school choice (with charter schools in place of vouchers), and, usually, ill-disguised dislike for the teacher unions. Accounts suggest that the foundation leaders are themselves impermeable to solid data that go against their favored reforms. They are also able to change course at whim, as they tire of spending millions to little effect: so did Bill Gates in abandoning the small schools project or, recently, in criticizing the achievement scores that his foundation had assiduously sponsored (Barkan, 2011; Kirp, 2013). What the foundations recommend is promoted or applied by the approved personnel they place in key positions, never more easily than since the appointment of Arne Duncan (their point man when he was the CEO of Chicago schools) to head the U.S. Department of Education.

Skepticism and mistrust of government are already vivid in American ideology; augmented by teachers' weariness, they preclude serious consideration of a civil service conception of career, while $77 \%$ of teachers desire career ladders (Feistritzer, 2011, 42). Added to these difficulties in the United States is the high cost of college, which excludes many prospective teachers from solid training programs since, after all, what is expected from them is often only a certificate.

Teachers need to learn how to teach, how to teach particular subjects and, of course, they need to master their subject matter (Mehta, 2013, 481). But in the United States, even being well-trained in specialized fields does not guarantee professional respect. Ingersoll finds that the frequent (but little-known) assignment of teachers to fields other than their own is a move by those in power that denies the professionalism of teachers; principals may use out-of-field assignments as carrot-and-stick incentives but Ingersoll sees them as a deeply deskilling practice that shows the low regard in which teaching is held: "analogous behavior in medicine, law or engineering could be considered malpractice and subject to litigation or prosecution" (Ingersoll, 2003, 167 and 158-167).

\section{Now, the feminization of teaching and the separation between universities and teacher practice exist in all advanced economies. The work of teachers, however, may be particularly difficult in the United States and not only because teacher professionalization has been weak. Child poverty and persistent racism coalesce in the difficult situation of our urban schools.}

Teachers are well aware of their occupation's low prestige, but perhaps less aware of the public esteem in which they are held, second only to the military in perceived contributions to society's well-being. The devaluation of teaching in the United States is, thus, contradictory. I believe that it is aided by the university's example: professors who dodge teaching care only about research that only their field cares about, and do not protest exceedingly against the shocking proliferation of contract academic labor. Also, teaching is devalued by the 
peculiarly American congeries of actors that attempt to regulate and change the schools from without: the new breed of reformers, says Diane Ravitch, "consists mainly of Wall Street hedge fund managers, foundation officials, corporate executives, entrepreneurs, and policymakers but few experienced educators" (Ravitch, 2012). As education blogger Valerie Strauss comments, "public schools have long been blamed when something happens to challenge the country's standing in the world. It happened when the Soviet Union launched the first space satellite, Sputnik, in 1957, and in 1983 when the Japanese automobile industry was booming and America's wasn't. Of course when the U.S. economy was roaring in the 1990s, you never heard anybody thank the public schools, but never mind" (Strauss, 2013).

The new breed of reformers does not seem wary of the huge business interests vested in testing, tutoring, and charter schools (Ravitch, 2011, footnote 8, 301-302); yet these interests place an unusual burden on U.S. teachers and schools, beginning with ubiquitous tests with ominous consequences. Finally, only the United States seems capable of greeting as saviors an influx of smart but untrained young graduates from the best colleges. In all the battles over policies, strategies, and, most importantly, budgets, what we could call the "nation-building" function of schools and teachers is forgotten: schools are agents of socialization that go beyond the labor market and often the only place where our most disadvantaged children find nurture.

\section{The crux of much-admired school systems in the world is not high performance on standardized tests, but respect for teaching and learning, for professionals, for children, for ideals of equality, and also, sometimes, for ideals of democratic governance within the schools.}

We have, in sum, a largely female occupation that its members choose because of their strong service ideal; an occupation from which the impossible is expected, while it is underpaid and without power; a profession which the largest majorities of teachers want to improve by gaining greater participation in decision-making at district and school levels ( $97 \%$ and $98 \%)$, removing incompetent teachers regardless of seniority ( $89 \%)$, basing salaries on education attained ( $81 \%)$, getting more autonomy in determining what and how they teach (78\%), and having career ladders within the ranks of teaching (77\%). They do not want to get rid of tenure or of teacher unions (Feistritzer, 2011, 42-45).

The future of teachers' professionalism cannot only lie in demonstrating technical competence, or in recruiting top students to the ranks. Teaching is a contested reality, which means that even respect for proven competence must be conquered. As they have done most recently in Chicago and Philadelphia, teachers enter the fray to defend both their jobs and the essential public service they provide. Getting rid of bureaucratic rules and regulations is the wrong move: they defend teachers against the arbitrary power of decision-makers and should not be misunderstood for what is oppressive in command hierarchies. Getting rid of unions is what powerful reform coalitions have been after for a long time, and it is also the wrong path.

The unions that exist today organized on an industrial model in the 1960s once the legal barriers to unionization were lifted. Their response to the disempowerment of teachers came after the McCarthyite witch hunts and purges of the 1950s had driven the last nail in the coffin of the more leftist Teachers Union. The latter had had long fought for a meaningful role in defining the work of teaching, the quality of public schools, and the citizenship of professional workers in their place of work; later, protecting members against very real attacks seemed to preclude a continuation of the former mission.

I believe that teachers have too little power without their unions, and little hope of improving their professional status without them. But the struggle for respect and voice must also be waged within teacher unions. As Albert Shanker argued, teachers must "Reform or be reformed" (in Mehta, 2013, 473).

Teachers can count on the already present public support and on their own service ethic to fight in defense of public schools, together with their constituent communities and with their unions. The combat is imposed, but it can embrace the reforms that teachers believe will improve their profession: participation in governance, autonomy, recognition of proven competence, space for real development and collaboration, and the responsibility to follow their students according to their own professional judgment.

The crux of much-admired school systems in the world is not high performance on standardized tests, but respect for teaching and learning, for professionals, for children, for ideals of equality, and also, sometimes, for ideals of democratic governance within the schools. This is not the place to go look for illustrations from Finland, Canada, South Korea, or Shanghai. We too have ideological resources with which to rekindle the "noble profession" of school teaching and the noble story of public schools. I would like to let Jefferson conclude with his words to William Jarvis in 1820: "I know no safe depository of the ultimate powers of the society, but the people themselves: and if we think them not enlightened enough to exercise their control with a wholesome discretion, the remedy is, not to take it from them, but to inform their discretion by education. This is the true corrective of abuses of constitutional power."

\section{References}

1. Abbott, Andrew D. 1988. The System of professions: An

Essay on the Division of Expert Labor. Chicago: University of Chicago Press.

2. Barkan, Joanne. 2011. "Got Dough? How Billionaires Rule our Schools." Dissent (Winter) 58, 1: 49-57. 
3. Callahan, Raymond. 1962. Education and the Cult of Efficiency. Chicago: University of Chicago Press.

4. Carnoy, Martin and Richard Rothstein. 2013. "PISA Day - An Ideological and Hyperventilated Exercise," Economic Policy Institute. Dec. 1 at www.epi.org/blog.

5. Ehrenreich, Barbara and John Ehrenreich. 2013. "Death of a Yuppie Dream: The Rise and Fall of the Professional-Managerial Class," Rosa Luxemburg Siftung. New York Office, at www.rosaluxnyc.org.

6. Feistritzer, Emily C. 2011. Profile of Teachers in the US 2011. Washington, DC: National Center for Education Information.

7. Fournier, Valerie. 1999. "The Appeal of Professionalism as a Disciplinary Mechanism." The Sociological Review, 47, 2: 280-307.

8. Freidson, Eliot. 1970. Professional Dominance: the Social Structure of Medical Care. New York: Atherton Press.

9. Groopman, Jerome. 2013. "The Quackish Cult of Alternative Medicine," The New Republic, October 19.

10. Hess, Frederick M. and Michael J. Petrilli. 2004. "The Politics of No Child Left Behind: Will the Coalition Hold?" Journal of Education, 185, 3: 13-25.

11. Hlavacik, Mark. 2012. "The Democratic Origins of Teachers' Union Rhetoric: Margaret Haley's Speech at the 1904 NEA Convention." Rhetoric and Public Affairs, 15, 3 (Fall): 499-524.

12. Hughes, Everett. 1971. The Sociological Eye: Selected papers on work, self, and the study of society. Chicago: Aldine-Atherton.

13. Ingersoll, Richard M. 2003. Who Controls Teachers' Work? Power and Accountability in America's Schools. Cambridge, Ma: Harvard University Press.

14. Keller, Bill. 2013 "An Industry of Mediocrity," New York Times op-ed, Oct. 20.

15. Kirp, David. 2013. "The Rebellion against High-stakes Testing." The Nation, May 27.

16. Labaree, David. 1992. "Power, Knowledge and the Rationalization of Teaching: A Genealogy of the Movement to Professionalize Teaching." Harvard Educational Review, 62, 2: 123154.

17. Ladd, Helen. 2012. "Presidential Address. Education and Poverty: Confronting the Evidence." Journal of Policy Analysis and Management, 31, 2: 203-227.

18. Lagemann, Ellen. 2000. An Elusive Science. Chicago: University of Chicago Press.

19. Larson, Magali Sarfatti. 1980. "Proletarianization and Educated Labor." Theory and Society, 9, 1: 131-175.

20. Larson, Magali Sarfatti. 1995. "Yo No Soy Tu Madre: Retórica y Realidad en una Reforma Escolar" in Volver a Pensar la
Educación. Vol II: Practicas y Discursos Educativos. Madrid: Ediciones Morata.

21. Larson, Magali Sarfatti. 2012. The Rise of Professionalism: Monopolies of Competence and Sheltered Markets. New Brunswick, N.J.: Transaction Publishers.

22. Lazerson, Marvin. 1984. "Teachers Organize: What Margaret Haley Lost." History of Education Quarterly, 24 (Summer): 261270.

23. Marshall, T.H. 1965. Class, Citizenship and Social Development. Garden City, N.Y.: Doubleday, Anchor.

24. Mehta, Jal. 2013. "From Bureaucracy to Profession: Remaking the Educational Sector for the Twenty-First Century." Harvard Educational Review, 83, 3 (Fall): 463-488.

25. Perkin, Harold. 1989. The Rise of Professional Society: England since 1880. New York: Routledge.

26. Polanyi, Karl. 1957. The Great Transformation. Boston: Beacon Press.

27. Popp Berman, Elizabeth. 2006. "Before the Professional Project: Success and Failure at Creating an Organizational Representative for English Doctors." Theory and Society, 35, 2: 157-191.

28. Ravitch, Diane. 2011. The Death and Life of the Great American School System. New York: Basic Books.

29. Ravitch, Diane. 2012. "Schools We Can Envy." New York Review of Books, March 12 and "How, and How Not to Improve the Schools." New York Review of Books, March 22.

30. Reader, W.J. 1966. Professional Men. London: Weidenfeld and Nicholson.

31. Sahlberg, Pasi. 2011. "Lessons from Finland." American Educator, Summer, 33-38.

32. Strauss, Valerie. 2013. "A debate: what do international test scores tell us?" The Answer Sheet. Washington Post blog. Nov 20.

33. Tawney, R.H. 1948. The Acquisitive Society. New York: Harcourt, Brace and World.

34. Wilensky, Harold. 1964. "The Professionalization of Everyone?" American Journal of Sociology, 70, 2: 137-158. 